\section{Relationship between Systemic Lupus Erythematosus T Cell Subsets, Anti-T Cell Antibodies, and T Cell Functions}

Chikao Morimoto, Ellis L. Reinherz, Judy A. Distaso, Alfred D. Steinberg, and Stuart F. Schlossman Division of Tumor Immunology, Dana-Farber Cancer Institute, Department of Medicine, Harvard Medical School, Boston, Massachusetts 02115; The Arthritis Branch, National Institute of Arthritis, Diabetes, Digestive and Kidney Diseases, National Institutes of Health, Bethesda, Maryland 20205

patients and the relative ability of their anti-T cell antibodies to kill T8+ cells vs. T4+ cells $(\gamma=0.666, P$ $<0.001)$. These results support the notion that in SLE different cellular defects in the immunoregulatory circuit underlie the development of autoimmune reactions and that the anti-T cell antibodies may cause numerical and functional deficiencies in $T$ cell subsets.

\section{Introduction}

Systemic lupus erythematosus (SLE) ${ }^{1}$ is a multisystem disease characterized by the spontaneous production of multiple autoantibodies (1), including antibodies reactive with lymphocytes (2-6). Since patients with SLE manifest lymphopenia (7-9) and impaired $T$ cell function (10-14), a relationship between the anti-lymphocyte antibodies and the impaired $T$ cell function has long been sought. Impaired suppressor $T$ cell function has been reported for many patients with SLE (15-21). Moreover, an attempt has been made to associate the dysfunction of suppressor function with the specific reactivities of the antibodies (22-26). In addition to suppressor cell dysfunction, a defect in inducer cell activity may be present in SLE patients, concomitant with, or independent of, suppressor cell abhormalities (27). Since inducer cells may be necessary for an induction of a variety of cellular functions (28-30), a defect in inducer cells could underlie defects in B cell activities, T cell-mediated effector functions, and/or suppressor cell functions. This last point is illustrated by the defect in the autologous mixed lymphocyte reaction in SLE (14). Although this defect has been associated with a defect in suppressor cell function (14), both the autologous mixed lymphocyte reaction and the suppressor cell function require inducer cells for optimal responses (31-35). Most studies of anti-lymphocyte antibodies from SLE patients have emphasized cold-reactive IgM antibodies $(5,24)$. However, the relevance of those antibodies to in vivo effects has been questioned. None-

1. Abbreviations used in this paper: $\mathrm{C}$, complement; $\mathrm{E}+$, sheep erythrocytes rosette-positive cells; $E-$, sheep erythrocytes rosette-negative cells; FACS, fluorescence-activated cell sorter; JRA, juvenile rheumatoid arthritis; PWM, pokeweed mitogen; SLE, systemic lupus erythematosus. 
theless, IgM anti-T cell antibodies appear to be important in the SLE-like disease of New Zealand mice (36). More recently, warm reactive SLE anti-lymphocyte antibodies of the IgG class have been shown to interfere with normal $\mathrm{T}$ cell function (37, 38). Therefore, it is likely that such antibodies may be important in the defective $T$ cell functions. Our earlier studies demonstrated that SLE patients with multisystem involvement had a decreased number of the $\mathrm{T} 5+/ \mathrm{T} 8+$ subset with a resulting increase in $\mathrm{T} 4+/ \mathrm{T} 8+$ ratio and that anti-T cell antibodies found in these patients were mainly reactive with the $\mathrm{T} 5+/ \mathrm{T} 8+$ suppressor $\mathrm{T}$ cell subset when the patients' sera were diluted extensively $(25$, 39). Studies in additional patients with SLE showed that many SLE patients, especially those with severe renal disease and/or thrombocytopenia without multisystem manifestations, had decreased numbers of $\mathrm{T} 4+$ inducer cells and a low $\mathrm{T} 4+/ \mathrm{T} 8+$ ratio $(40,41)$.

In the present study, we wished to determine whether or not there might be a relationship between the $T$ lymphocyte subsets present in SLE patients and the specificity of the anti-T cell antibodies in those patients. Finally, we attempted to characterize the functional subsets that the anti-T cell antibodies defined.

\section{Methods}

Isolation of lymphoid populations. Human peripheral blood mononuclear cells were isolated from healthy volunteer donors by Ficoll-Hypaque density gradient centrifugation (Pharmacia Fine Chemicals, Piscataway, $\mathrm{NJ}$ ). Unfractionated mononuclear cells were first depleted of macrophages by adherence to plastic as previously described (42). The adherent cells were recovered and used as a macrophage-enriched population. The macrophage-depleted mononuclear cells were separated into E-rosettepositive $(\mathrm{E}+)$ and $\mathrm{E}$-rosette-negative $(\mathrm{E}-)$ populations with $5 \%$ sheep erythrocytes (Microbiological Associates, Bethesda, MD). The rosetted mixture was layered over Ficoll-Hypaque and the recovered E+ pellet treated with $0.155 \mathrm{M} \mathrm{NH}_{4} \mathrm{Cl}$ to lyse erythrocytes. The $\mathrm{T}$ cell population obtained was $>95 \% \mathrm{E}+$ and $>94 \%$ reactive with a monoclonal antibody anti-T3, which defines an antigen present on all mature peripheral $T$ lymphocytes (43). The E- population was highly enriched for B cells by complement (C)-mediated lysis with anti-monocyte antibody, antiMol. This rationale was used since it was previously shown that Epopulations contained many null cells that are reactive with anti-Mol antibody (44). Reanalysis of anti-Mol-lysed subpopulations of E- cells (B cells) demonstrated that $<5 \%$ anti-Mol-reactive cells and $>90 \%$ of cells were reactive with anti-B1 monoclonal antibody, which defines an antigen present on all peripheral B cells (45).

Source of patients' lymphocytes and plasma. Plasma from 55 patients satisfying the diagnostic criteria of the American Rheumatism Association for SLE who were admitted to the Arthritis Branch of the National Institute of Arthritis, Diabetes, and Kidney Diseases, Bethesda, MD were screened for the presence of anti-T cell antibodies by $\mathrm{C}$-mediated lysis. For screening anti-T cell antibodies in SLE, $5 \times 10^{5} / 0.1 \mathrm{ml}$ of pooled $\mathrm{T}$ cells from four individuals were mixed with $20 \mu \mathrm{l}$ SLE plasma and incubated for $50 \mathrm{~min}$ (final plasma dilution $1: 5$ ) at $4^{\circ} \mathrm{C}$. The same volume of rabbit $\mathrm{C}$ (Pel-Freeze Biologicals, Rogers, AK) was then added to this mixture and further incubated for $3 \mathrm{~h}$ at $15^{\circ} \mathrm{C}$. Percentage of killing was examined for the trypan blue dye exclusion method. It should be noted that when screening anti-T cell antibodies in SLE, decreasing numbers of $T$ cells and/or increasing concentration of plasma resulted in increasing numbers of patients' plasma that killed T cells $>20 \%$. However, our purpose for screening anti-T cell antibodies was to find "good plasma" that can kill $\mathrm{T}$ cells even though using large numbers of $T$ cells. Thus, when we screened plasma, we used the method as described above. Of these, 24 killed $>20 \%$ of normal T cells. These were selected for further study. The anti-T cell antibodies in such plasma were confirmed by indirect immunofluorescence using peripheral $\mathrm{T}$ cells on the fluorescence-activated cell sorter (FACS). Lymphocytes for analyzing of the patients' $T$ cell subsets were obtained at the same time as plasma for analysis of anti-T cell antibodies. In most cases, this was before any treatment except nonsteroidal antiinflammatory drugs. Only five patients had been receiving low doses of prednisone $(\leq 10 \mathrm{mg} / \mathrm{d})$. All SLE plasma used had been fresh frozen and had not been previously thawed. All plasma was centrifuged at $105,000 \mathrm{~g}$ for $2 \mathrm{~h}$ at $4^{\circ} \mathrm{C}$ to remove aggregates of immune complexes before use. Formal study by Clq binding assay shows that complexes are removed by such centrifugation. Background killing by rabbit $\mathrm{C}$ was always $<5 \%$.

Complement-dependent lysis of lymphocytes with monoclonal antibodies. E+ lymphocytes were treated with anti-T4 or anti-T8 monoclonal antibodies and rabbit $\mathrm{C}$ (Pel-Freeze Biologicals). These antibodies of the IgG2 subclass have been described elsewhere $(27,28,46)$. Briefly, $2 \times 10^{7}$ cell aliquots were incubated with $1 \mathrm{ml}$ of antibody at a 1:250 dilution for $1 \mathrm{~h}$ at room temperature and then $0.3 \mathrm{ml}$ rabbit $\mathrm{C}$ was added to the mixture. The mixture was incubated for another hour in a $37^{\circ} \mathrm{C}$ shaking water bath, washed, and residual cells cultured overnight at $37^{\circ} \mathrm{C}$. After lysis of cells with anti-T4 and $\mathrm{C},>90 \%$ of the residual cells were $\mathrm{T} 8+$ cells whereas $<5 \%$ were $\mathrm{T} 4+$ cells, after lysis with anti$\mathrm{T} 8$ and $\mathrm{C},>90 \%$ of the remaining cells were $\mathrm{T} 4+$ cells and $<5 \%$ were $\mathrm{T} 8+$ cells. These two populations will be referred to as $\mathrm{T} 8+$ and $\mathrm{T} 4+$ subsets, respectively.

Juvenile rheumatoid arthritis (JRA) serum. Serum from a patient with JRA used in this study was described in detail $(34,47,48)$. In brief, the patient was experiencing severe disease activity at the time of blood sampling. The samples contained anti-T cell antibodies reactive with an average $27 \%$ of $T$ cells and with $\sim 40 \%$ of $T 4+T$ cells. The patient who was defined as having severe active disease exhibited at least two of the following symptoms: polyarticular synovitis, high fever, skin rash, or iridocyclitis. Serum from this patient reacted similarly at dilutions of $1: 5$ to $1: 10$.

Determination of immunoglobulin (Ig) class of anti-T cell antibodies. The monospecific anti-human IgM and anti-human IgG sera were purchased from Miles Laboratories, Inc., Elkhart, IN and further purified by elution from appropriate immunoabsorbent columns. These antisera were then coupled to $\mathrm{BrCn}$-activated Sepharose $4 \mathrm{~B}$ as outlined by the manufacturer (Pharmacia Fine Chemicals). To determine the Ig classes of the anti-T cell antibodies, SLE plasma was passed through a column of Sepharose 4B coupled with one or another antiserum, and subsequently the functional activity of anti-T cell antibodies of the passed plasma was compared with that of an aliquot of SLE plasma that was passed through a column of uncoupled unactivated Sepharose 4B.

C-dependent lysis of lymphocytes with SLE plasma. T4+ or T8+ cells were treated with SLE plasma and $C$ as previously described (24). Briefly, $2 \times 10^{7} \mathrm{~T} 4+$ or $\mathrm{T} 8+$ cells were incubated in $1 \mathrm{ml}$ of SLE plasma (1:5 dilution; one plasma was studied at 1:40) containing anti-T cell antibodies for $50 \mathrm{~min}$ at $4^{\circ} \mathrm{C}$. An equal volume of $\mathrm{C}$ was added to each tube, and the cells were incubated for an additional $3 \mathrm{~h}$ at $15^{\circ} \mathrm{C}$. The lysed cells were then washed and placed in final media for functional studies. Control T4+ or T8+ cells were treated with AB plasma and/ or $\mathrm{C}$ and background killing of these cells by $\mathrm{C}$ was $<5 \%$. 
Detection of in vitro secretion of $I g G$. Unfractionated and separated populations of lymphocytes were cultured in round-bottomed microtiter plates (Falcon Labware, Div. of Becton, Dickinson \& Co., Oxnard, CA) in RPMI 1640 medium supplemented with $20 \%$ heat-inactivated fetal calf serum (Microbiological Associates), $0.5 \%$ sodium bicarbonate, and $1 \%$ penicillin-streptomycin at $37^{\circ} \mathrm{C}$ in a humid atmosphere containing $5 \% \mathrm{CO}_{2}$ for $7 \mathrm{~d}$. To determine the effect of subpopulations of the T4+ subset on suppressor inducer functions, $2 \times 10^{4}$ unfractionated T4+ cells or T4+ cells treated with SLE plasma and C were added to $5 \times 10^{4}$ $B$ cells. To this was added $0.1 \mathrm{ml}$ of pokeweed mitogen (PWM) at a 1:50 dilution, and various numbers of unfractionated T8 cells in a total volume of $0.2 \mathrm{ml}$.

Macrophages were added to all wells at the initiation of in vitro cultures at a $5 \%$ final concentration. In some experiments, various numbers of $\mathrm{T} 8$ cells treated with SLE plasma and $\mathrm{C}$ were added to a mixture of $2 \times 10^{4}$ unfractionated T4+ cells and $5 \times 10^{4}$ B cells with PWM. On day 7 , cultures were terminated, supernatants harvested, and IgG secretion into the supernatant determined by solid phase radioimmunoassay utilizing a monoclonal antibody directed at the Fc portion of the human gamma heavy chain (anti-gamma Fc) (gift of Dr. V. Raso, Dana-Farber Cancer Institute) as previously described (34).

\section{Results}

Subdivision of SLE anti-T cell antibodies into four groups

Recent studies have demonstrated that the T4+ subsets can be subdivided into the $\mathrm{T} 4+$ helper, and $\mathrm{T} 4+$ suppressor inducer subset $(34,35,47,48)$. To determine the fine specificity and functional characteristics of $T$ cell subsets with which SLE anti-T cell antibodies react, the following experiments were performed. Normal T4+ cells were treated with SLE plasma and $C$ (to examine whether or not suppressor inducer cells were killed) and the residual viable T4 cells were mixed with B cells in the presence of PWM. To this mixture were added varying numbers of normal T8+ cells to determine whether or not they suppress PWM-induced IgG synthesis. In reciprocal studies, normal $\mathrm{T} 8+$ cells were treated with SLE plasma and C (to determine whether or not suppressor effector cells were killed), and the residual viable $\mathrm{T}$ cells were added to a mixture of $\mathrm{B}$ cells and control T4+ cells in the presence of PWM. Table I shows representative results from the 14 patients studied most extensively. PWM-stimulated IgG synthesis was measured after treatment with anti-T cell antibodies of either T4+ or T8 + cells. The table shows the functional effects of different SLE anti-T cell antibodies on $\mathrm{T} 4+$ and $\mathrm{T} 8+$ subsets. From these results, patients can be subdivided into four groups: A, B, C, and D.

SLE patients whose plasma fell into group A demonstrated two effects. Pretreatment of normal T4+ cells with SLE anti-T cell antibodies resulted in an inability of normal T8+ cells to suppress IgG synthesis. Therefore, the SLE anti-T cell antibodies interfered with suppressor inducer function of the $\mathrm{T} 4+$ population. In addition, treatment of T8+ cells with SLE anti-T cell antibodies led to loss of suppressor effector function, suggesting that the SLE anti-T cell antibodies eliminated suppressor effector cells. In group B, pretreatment of T4+ cells had no effect on suppression, indicating no effect on suppressor
Table I. Subdivision of SLE Anti-T Cell Antibodies into Four Groups

\begin{tabular}{llll}
\hline & \multicolumn{3}{c}{ Percent suppression of IgG synthesis* } \\
\cline { 2 - 4 } $\begin{array}{l}\text { Group of SLE anti-T } \\
\text { cell antibodies }\end{array}$ & $\begin{array}{l}\text { B + T4+ } \\
+ \text { T8+ }\end{array}$ & $\begin{array}{l}\text { B + T4+ SLE } \\
\text { Rx + T8+ }\end{array}$ & $\begin{array}{l}\text { B + T4+ + T8+ } \\
\text { SLE Rx }\end{array}$ \\
\hline A (6)§ & 63 & 3 & 5 \\
B (3) & 87 & 78 & 3 \\
C (3) & 68 & 9 & 60 \\
D (2) & 78 & 73 & 67 \\
\hline
\end{tabular}

* Percent suppression was calculated by comparing the IgG secretion with and without the addition of T8+ cells to the cultures. The T8+ cells suppressed in control cultures. That suppression was eliminated by pretreatment of either T4+ cells (group A and C, center column) or $\mathrm{T}^{+}$cells (group A and B, right column) with SLE anti-T cell antibodies and $\mathrm{C}$.

$\ddagger$ Normal T4+ and T8+ T cells and B cells and macrophages were stimulated with PWM and assayed for IgG synthesis. In addition, either the T4+ or the T8+ cells were pretreated with SLE anti-T cell antibodies and $C$. Pretreatment with SLE anti-T cell antibodies from different patients resulted in loss of suppressor effector function (group B), suppressor inducer function (group C), both (group A), or neither (group D).

$\S$ Number in parentheses shows the number of patients represented. See Figs. 5-7 for the data from all 24 patients.

inducer function. However, there was a marked inhibition of suppression by pretreating the T8+ cells with SLE anti-T cell antibodies, indicating preferential elimination of $\mathrm{T} 8+$ suppressor effector functions. Group $\mathrm{C}$ patients had anti-T cell antibodies that eliminated $\mathrm{T} 4+$ suppressor inducer functions, but that did not eliminate T8+ suppressor effector functions. Group D patients had anti-T cell antibodies that did not eliminate either function. Detailed data from these 14 patients are shown in Table II. Group A anti-T cell antibodies, which were capable of eliminating both $\mathrm{T} 4+$ suppressor inducer function and T8+ suppressor effector function generally manifested the greatest degree of killing against both $\mathrm{T} 4+$ and $\mathrm{T} 8+$ cells; however, individual plasma in other groups killed as well as did individual plasma in group A. Group B anti-T cell antibodies tended to kill T8 + cells preferentially, consistent with their ability to eliminate suppressor effector function; however, the plasma of patient 9 had substantial killing of T4+ cells and had no effect on T4+ suppressor inducer function. Plasma from group $C$ patients effectively eliminated $\mathrm{T} 4+$ suppressor inducer function, but had only modest killing of $\mathrm{T}$ cells and there was no special preference for $\mathrm{T} 4+$ cells in the killing.

\section{Effect of SLE anti-T cell antibody treatment of different donors' lymphocytes on IgG production}

To study further the reproducibility of the data shown in Table II, the effect of SLE anti-T cell antibody treatment of different donors' T4 and T8 cells on IgG production was studied. As 
Table II. Detailed Results of PWM-stimulated IgG Synthesis after Treatment of T Cells with Anti-T Cell Antibodies from 14 SLE Patients

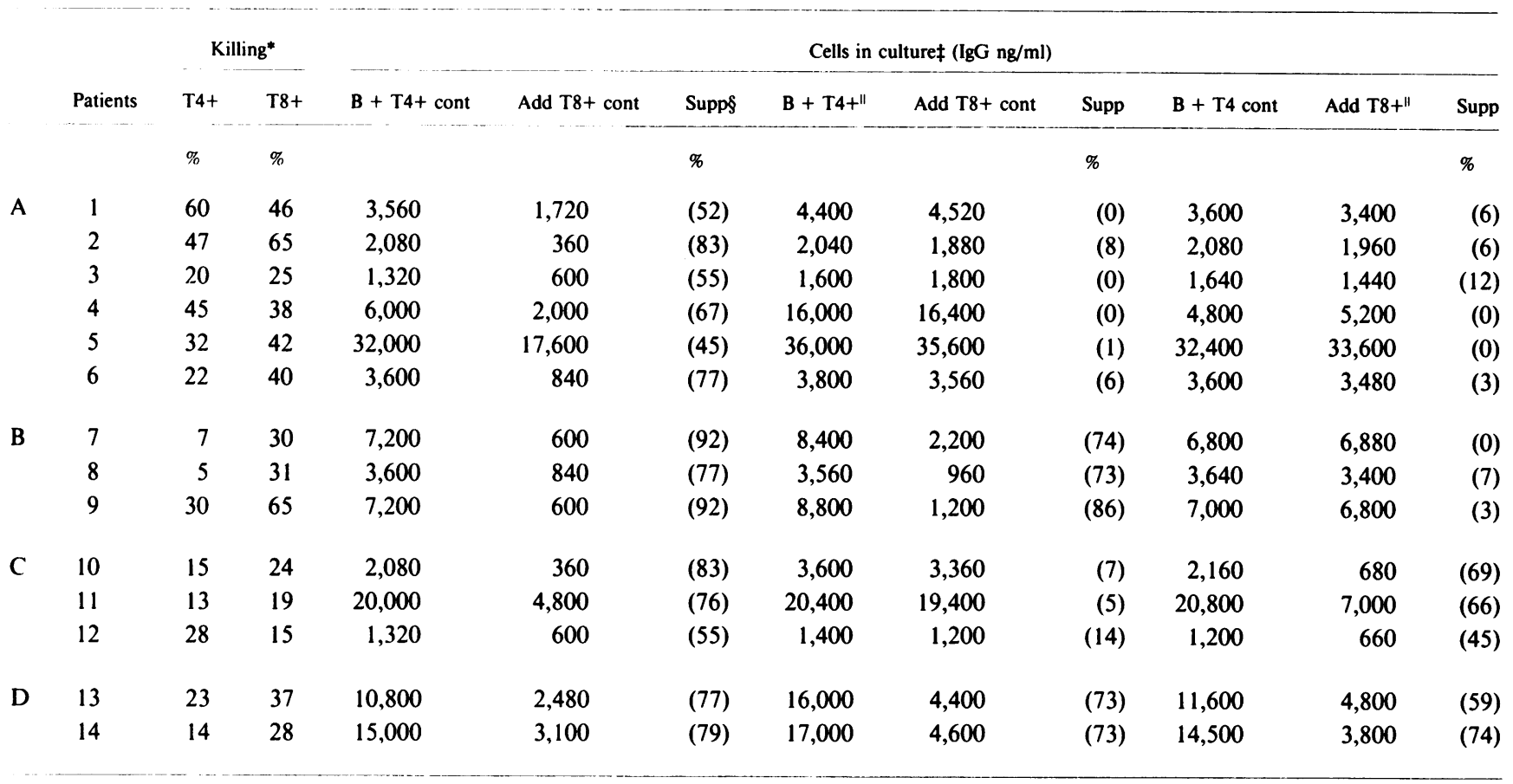

T4 and T8 cont, T4 and T8 cells treated with AB plasma and C; Supp, supression. * Plasma dilution was 1:5 except for patient 2 (1:40). $¥ 5$ $\times 10^{4} \mathrm{~B}$ cells and $2 \times 10^{4} \mathrm{~T} 4+$ cells in the presence of PWM in each culture. In some experiments, $2 \times 10^{4} \mathrm{~T} 8+$ cells are added to this mixture. § Percent suppression was calculated from the following formula: (Control IgG - IgG observed by treatment of SLE plasma)/(control IgG production) $\times 100$. "Cells treated with SLE plasma containing anti-T cell antibodies and $C$ and then adjusted to viable cell number. Control $\mathrm{T} 4+$ and $\mathrm{T} 8+$ cells were treated with $\mathrm{AB}$ plasma and/or complement.

shown in Table III, a similar tendency of the percentage of suppression was observed in each patient's plasma.

Effect of SLE plasma treatment with no killing or $<20 \%$ $T$ cell killing of lymphocytes on IgG production

To determine whether SLE plasma containing anti-T cell antibodies with no killing or $<20 \% \mathrm{~T}$ cell killing demonstrate the same kinds of effects, we examined the effect of SLE plasma treatment with no or $<20 \% \mathrm{~T}$ cell killing of lymphocytes on IgG production. For this purpose, we used four patients' plasma. As shown in Table IV, even though T4 or T8 cells were treated with SLE plasma and C, no functional changes were observed. The results in these four patients suggest that a threshold of at least certain killing of $T$ cells by SLE plasma seems necessary to cause a detectable change in lymphocyte function.

\section{Ig class of anti-T cell antibodies in SLE patients}

To determine the Ig class of anti-T cell antibodies in SLE patients of these systems, SLE plasma was passed through both antihuman IgM- and IgG-conjugated Sepharose 4B columns and the passed plasma was examined for residual anti-T cell antibody activity as described above. As a control, the SLE plasma was also passed through a control Sepharose 4B column pretreated with bovine serum albumin. Table $\mathrm{V}$ shows the results of three SLE plasmas as described in Table II after passing through Sepharose 4B columns. As shown in Table $V$, when SLE plasma was passed through anti-human IgM-conjugated columns, the plasma did not contain anti-T cell antibodies that interfered with suppressor functions. However, when SLE plasma was passed through anti-human IgG-conjugated columns, no change of interference with suppressor function was observed. Thus, the activity of anti-T cell antibodies in our systems seemed to reside in the IgM fraction.

\section{Dose-response curves for suppressor inducer and suppressor effector functions}

Group A. Fig. 1 describes the functional characteristics of $\mathrm{T}$ cell subsets that anti-T cell antibodies of group A defined. When increasing numbers of $\mathrm{T} 8+$ cells were added to control T4+ and $B$ cells, a marked reduction of IgG production was observed. Thus, in patient 1 , percent suppression was increased from 0 to $52 \%$ when $2 \times 10^{4} \mathrm{~T} 8+$ cells were added to the control T4+ and $B$ cell mixtures. In contrast, when $\mathrm{T} 8+$ cells were added to the mixture of T4+ cells, pretreated with SLE plasma from 
Table III. Effect of SLE Anti-T Cell Antibody Treatment of Different Donors' Lymphocytes on IgG Production

\begin{tabular}{|c|c|c|c|c|c|c|c|c|c|}
\hline \multirow{2}{*}{ SLE plasma } & \multicolumn{9}{|c|}{ Percent suppression of $\operatorname{lgG}$ synthesis* } \\
\hline & \multicolumn{3}{|c|}{ Subject 1} & \multicolumn{3}{|c|}{ Subject 2} & \multicolumn{3}{|c|}{ Subject 3} \\
\hline Patient 1 & $52 \ddagger$ & 0 & 6 & 70 & 5 & 10 & 62 & 11 & 9 \\
\hline Patient 4 & 67 & 0 & 0 & ND§ & ND & ND & 50 & 9 & 7 \\
\hline
\end{tabular}

* Normal T4 and T8 T cells and B cells and macrophages were stimulated with PWM and assayed for IgG synthesis. In addition, either the T4+ (T4Rx) or the T8 cells (T8Rx) were pretreated with SLE plasma and C. ‡ Percent suppression was calculated as described in Table I. $\S \mathrm{ND}$, not done.

patient 1 plus $\mathrm{C}$, and $\mathrm{B}$ cells, no suppression was observed. When T8+ cells, treated with SLE patient 1 plasma and C, were added to the mixture of untreated $\mathrm{T} 4+$ and $\mathrm{B}$ cells, no suppression was observed (Fig. 1). Similar results were observed in patient 5 (Fig. 1). Thus, after killing of either T4+ or T8+ cells with SLE plasma of group A, suppressor function was lost. However, at excess numbers of T8+ cells, suppression was observed. These results suggest that anti- $T$ cell antibodies found in group $\mathrm{A}$ were reactive with both the $\mathrm{T} 4+$ suppressor inducer subset and the T8+ suppressor effector subset.

Group B. Fig. 2 describes the functional characteristics of $T$ cell subsets defined by anti-T cell antibodies of group $B$. When increasing numbers of $\mathrm{T} 8+$ cells were added to the mixture of B cells and T4+ cells, treated with plasma from patient 8 or 9 and $C$, marked suppression of IgG synthesis was observed, similar to the suppression observed with the combination of T4+ control and $\mathrm{B}$ cells. In contrast, when $\mathrm{T} 8+$ cells, treated with plasma from patient 8 or 9 and $\mathrm{C}$, were added to the mixture of T4+ control and $B$ cells, increasing suppression was not observed until the addition of $8 \times 10^{4} \mathrm{~T} 8+$ cells. With the addition of excess numbers of $\mathrm{T} 8+$ cells, suppression was observed. These results suggest that anti- $T$ cell antibodies found in group $B$ were reactive with the $\mathrm{T} 8+$ suppressor effector subset and not with the $\mathrm{T} 4+$ suppressor inducer subset.

Group $C$. Fig. 3 describes the functional characteristics of $T$ cell subsets defined by anti-T cell antibodies of group $C$. When increasing numbers of control $\mathrm{T} 8+$ cells were added to the mixture of $\mathrm{B}$ cells and $\mathrm{T} 4+$ cells treated with patient plasma 10 or 12 and $C$, marked suppression of IgG production was not observed. In contrast, when $\mathrm{T} 8+$ cells, treated with these SLE plasma and C, were added to the mixture of control T4+ and B cells, marked suppression of IgG production was still observed. These results suggest that anti-T cell antibodies from group $\mathrm{C}$ were predominantly reactive with the $\mathrm{T} 4+$ suppressor inducer subset and not reactive with the $\mathrm{T} 8+$ suppressor effector subset.

Group D. Even though T8+ or T4+ cells were treated with SLE plasma and C, marked suppression of IgG synthesis was observed. These results suggest that anti-T cell antibodies from group D could not eliminate functional $\mathrm{T} 4+$ suppressor inducer cells or T8+ suppressor effector cells (Fig. 4). Such antibodies could be reactive with other functional subsets not defined in our assay system (e.g., helper or amplifier cells, inducer cells for $\mathrm{T}$ cell-mediated immunity, nonsuppressor effector $\mathrm{T}$ cells).

Reactivity of JRA anti-T cell antibodies with residual T4 cells after lysis of SLE antibodies and C

Our earlier data indicated that the T4 population could be separated into T4+JRA - inducer and T4+JRA+ suppressor inducer subpopulations $(34,47,48)$. The reactivity of JRA anti- $T$ cell antibodies with residual T4 cells after lysis with SLE antibodies and $\mathrm{C}$ was determined. For this purpose, control T4 cells and the T4 cells that were treated with SLE plasma and $\mathrm{C}$ were compared.

As shown in Table VI, $>95 \%$ of cells treated with anti-T8 and $C$ were T4. Approximately $40 \%$ of control T4 cells stained with JRA anti-T cell antibodies. However, after lysis of T4 cells with SLE plasma and C, the JRA reactivity was different. For example, the JRA reactivity of T4 cells treated with SLE plasma from patients 2, 4 (group A), and 12 (group C) was markedly decreased. In contrast, that of T4 cells treated with SLE plasma from patient 7 (group B) was not changed. These results also

Table IV. Effect of SLE Plasma Treatment with No or Less Than 20\% T Cell Killing of Lymphocytes on IgG Production

\begin{tabular}{|c|c|c|c|c|c|c|}
\hline \multirow[b]{2}{*}{ SLE plasma } & \multicolumn{3}{|c|}{ Killing } & \multicolumn{3}{|c|}{ Suppression of IgG synthesis* } \\
\hline & $\mathrm{T}$ & T4 & T8 & Control & $\mathrm{T} 4 \mathrm{Rx}$ & T8Rx \\
\hline & $\%$ & $\%$ & $\%$ & $\%$ & $\%$ & $\%$ \\
\hline Patient 27 & 11 & 8 & 6 & $72 \ddagger$ & 62 & 75 \\
\hline Patient 33 & 9 & $<5$ & 7 & 57 & 59 & 55 \\
\hline Patient 35 & 7 & $<5$ & 6 & 61 & 57 & 59 \\
\hline Patient 46 & $<5$ & $<5$ & $<5$ & 76 & 69 & 73 \\
\hline
\end{tabular}

* Normal T4 and T8 T cells, B cells and macrophages were stimulated with PWM and assayed for IgG synthesis. In addition, either the T4+ (T4Rx) or the T8 cells (T8Rx) were pretreated with SLE plasma and $C$.

$\ddagger$ Percent suppression was calculated as described in Table I. 
Table V. Ig Class of Anti-T Cell Antibodies in SLE

\begin{tabular}{|c|c|c|c|c|c|c|c|c|c|}
\hline \multirow[b]{3}{*}{ SLE plasma } & \multicolumn{9}{|c|}{ Percent suppression of lgG synthesis* } \\
\hline & \multicolumn{3}{|c|}{ Unabsorbed } & \multicolumn{3}{|c|}{ IgM absorbed } & \multicolumn{3}{|c|}{ IgG absorbed } \\
\hline & Control & T4Rx & T8Rx & Control & T4Rx & T8Rx & Control & T4Rx & T8Rx \\
\hline Patient 5 & $50 \ddagger$ & 2 & 3 & 54 & 52 & 49 & 52 & 3 & 4 \\
\hline Patient 9 & 80 & 75 & 2 & 81 & 79 & 82 & 81 & 79 & 3 \\
\hline Patient 12 & 62 & 20 & 59 & 60 & 58 & 63 & 61 & 21 & 55 \\
\hline
\end{tabular}

* Normal T4 and T8 T cells and B cells and macrophages were stimulated with PWM and assayed for IgG synthesis. In addition, either the T4+ (T4Rx) or the T8 cells (T8Rx) were pretreated with SLE plasma and C, specifically depleted of IgG or IgM on an anti-IgG or anti-IgM Sepharose 4B column, respectively. Unabsorbed plasma were passed over a control Sepharose 4B column pretreated with bovine serum albumin. $¥$ Percent suppression was calculated as described in Table $I$.

support the notion that after treatment with SLE plasma from group A and C, T4 suppressor inducer cells were eliminated since JRA anti-T cell antibodies can define the T4 suppressor inducer subsets $(34,46,47)$. With regard to the reactivity of SLE anti-T cell antibodies with T4 inducer of B cell help, SLE anti- $T$ cell antibodies are relatively less reactive with these populations, since even though T4 cells were treated with SLE plasma and C, IgG synthesis by B cells with treated T4 cells were not changed or in some cases, enhanced.

\section{Reactivity of SLE anti-T cell antibodies with} radiosensitive and radioresistant $T 4$ cells

Previous studies showed that T4+ cells helping for B cell Ig production were relatively radioresistant and T4+ cells of suppressor inducer function were radiosensitive $(35,47)$. Next we examined the reactivity of SLE anti-T cell antibodies (SLE plasma with presumed reactivity for $\mathrm{T} 4$ cells) with radiosensitive and radioresistant T4+ cells. To examine reactivity of SLE anti- $\mathrm{T}$ cell antibodies with radioresistant $\mathrm{T} 4+$ cells, $\mathrm{T} 4+$ cells were treated with SLE plasma and C and residual viable T4+ cells were irradiated $(1,250 \mathrm{rad})$ or not irradiated. $5 \times 10^{4} \mathrm{~B}$ cells and $1 \times 10^{5}$ irradiated or nonirradiated T4+ cells treated with SLE plasma and C were stimulated with PWM. As shown in Table VII, even after irradiation of T4+ cells treated with SLE plasma and C, Ig production by B cells was not changed. To examine the relationship of $\mathrm{T} 4+$ radiosensitive and $\mathrm{T} 4+$ cells reactive with SLE anti-T cell antibodies, the effect of removal of these two subsets of T4+ cells on suppression of PWMstimulated Ig synthesis was studied in parallel. Thus, untreated $\mathrm{T} 4+$, irradiated $\mathrm{T} 4+$, or $\mathrm{T} 4+$ cells pretreated with SLE plasma and $C$ were added to a constant number of $B$ cells in the presence or absence of T8+ cells. As shown in Table VIII, when T8+ cells were added to a mixture of irradiated $\mathrm{T} 4+$ and $\mathrm{B}$ cells, no suppression of Ig synthesis was observed (Table VIII, part B). In contrast, when unirradiated T4+ cells were added to the mixture of irradiated T4+ and B cells, the addition of T $8+$ cells was associated with a decreased amount of Ig synthesis (Table VIII, part C). However, pretreatment of unirradiated T4+ cells with SLE plasma belonging to group $A$ and $C$ abrogated the

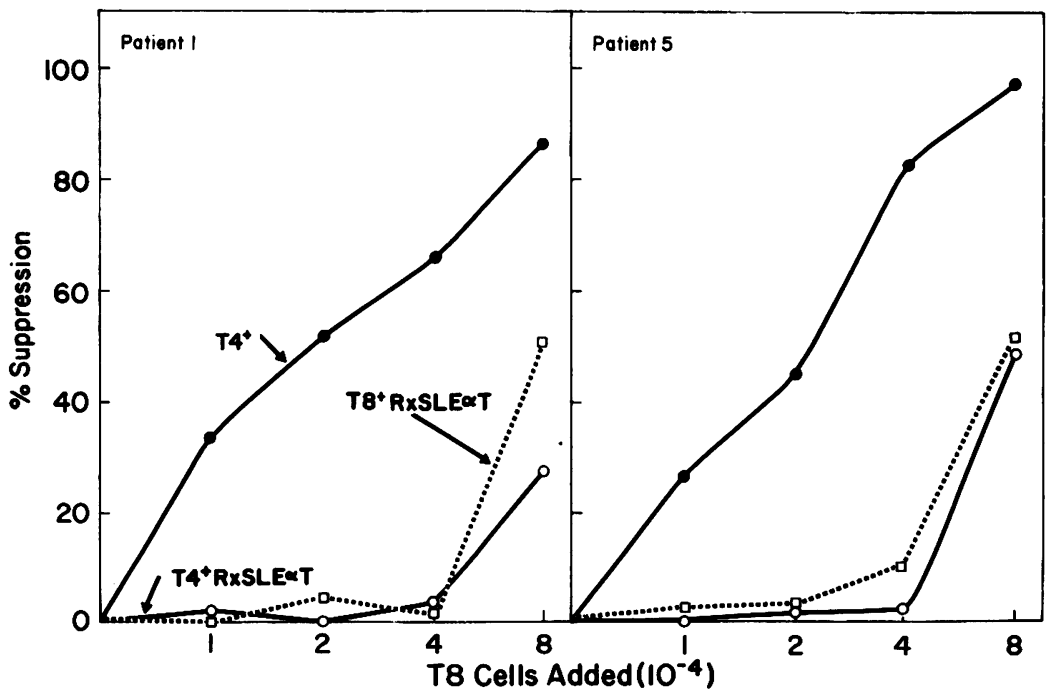

Figure 1. The functional characteristics of $\mathrm{T}$ cell subsets that anti-T cell antibodies of group A defined. T4+ cells were treated with SLE plasma and $C$ and residual viable $\mathrm{T} 4+$ cells were mixed with $\mathrm{B}$ cells in the presence of PWM. To this mixture were added varying numbers of $\mathrm{T} 8+$ cells to examine the effect on PWM-induced IgG synthesis. In reciprocal studies, T8+ cells were treated with SLE plasma and C, and the residual viable $\mathrm{T} 8+$ cells were added to a mixture of $B$ cells and control T4+ cells in the presence of PWM. Control T4+ or T8+ cells were treated with $A B$ plasma and/or $C$. The results of studies with plasma from patients 1 and 5 from Table II are shown. 


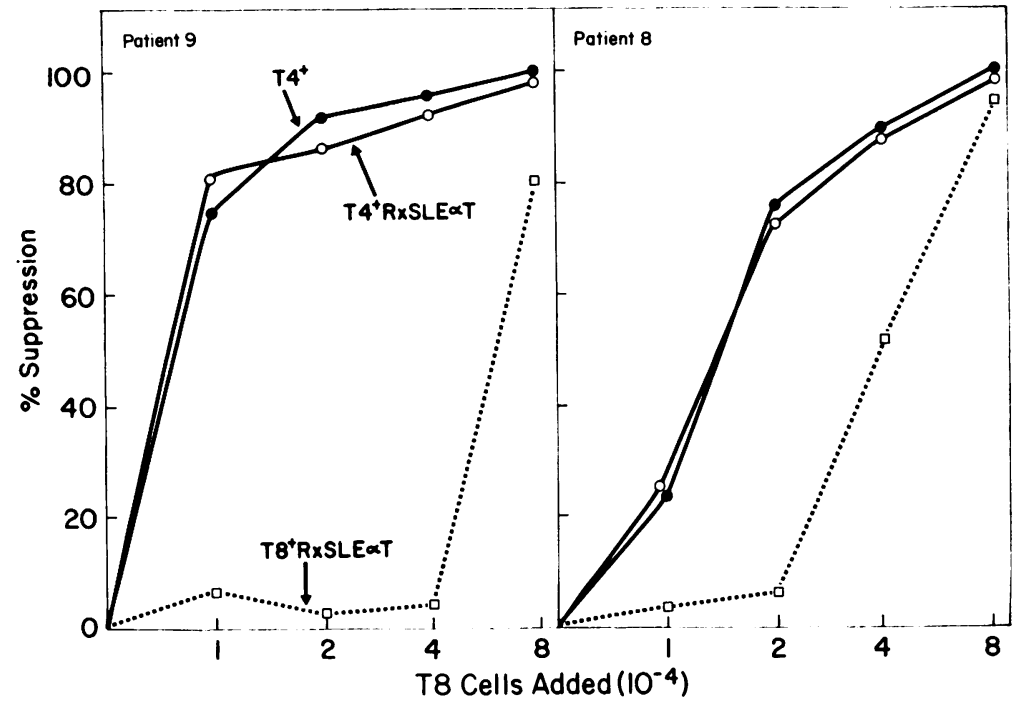

Figure 2. The functional characteristics of $T$ cell subsets that anti-T cell antibodies of group B defined. The results of studies with plasma from patients 8 and 9 are shown. capacity of the irradiated T4+ cells to help induce suppression (Table VIII, part D). These results indicate that radiosensitive T4+ suppressor inducer cells and T4+ subpopulations reactive with SLE anti-T cell antibodies are functionally related, again supporting the notion that SLE anti-T cell antibodies belonging to group $A$ and $C$ were reactive with radiosensitive $T 4+$ suppressor inducer cells but not reactive with radioresistant $\mathrm{T} 4+$ cells.

Effect of SLE plasma treatment after absorption of B cell lines on $\operatorname{Ig} G$ production

To exclude the possibility that anti-Ia antibodies containing SLE plasma may affect T4 or T8 interaction with macrophages or Ia+ B cells, three SLE plasmas were absorbed with EpsteinBarr virus-transformed B cell lines expressing Ia molecules on their cell surfaces extensively and then compared the functional effect of SLE anti-T cell antibodies of absorbed or nonabsorbed plasma on IgG synthesis. As shown in Table IX, even though SLE plasma was absorbed with B cell lines, and then T4+ or $\mathrm{T} 8+$ cells were treated with this plasma and $\mathrm{C}$, similar functional results were obtained. Thus, this possibility is unlikely.

Relationship between $T$ cell subset killing and $T$ cell function reduction

We examined whether the functional effects of the anti-T cell antibodies of these four groups had any relationship to their

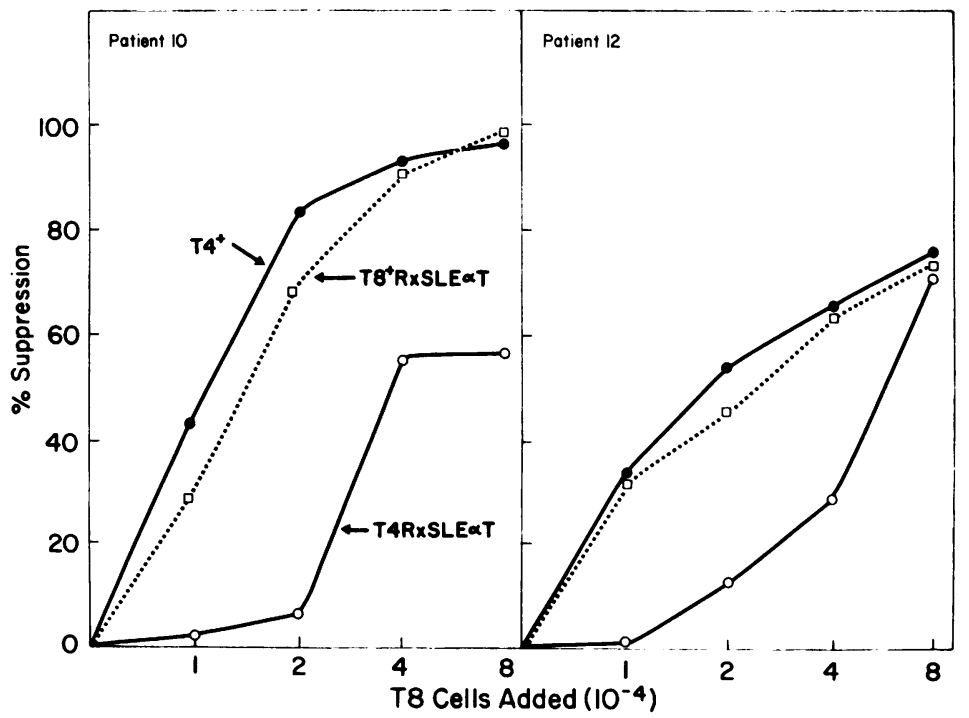

Figure 3. The functional characteristics of $\mathrm{T}$ cell subsets that anti- $T$ cell antibodies of group $C$ defined. The results of studies with plasma from patients 10 and 12 are shown. 


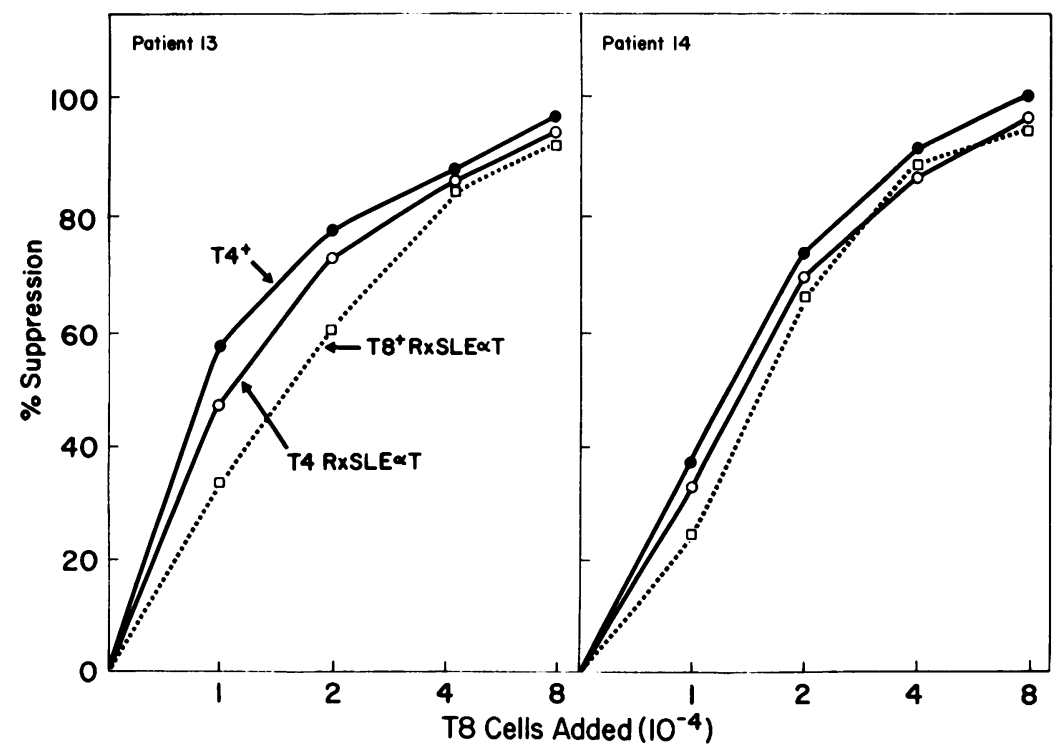

Figure 4. The functional characteristics of $\mathrm{T}$ cell subsets that anti-T cell antibodies of group $\mathrm{D}$ defined. The results of studies with plasma from patients 13 and 14 are shown. ability to kill T4+ and T8+ subsets. As shown in Fig. 5, the killing ratio of the $\mathrm{T} 8+$ subset to $\mathrm{T} 4+$ subset by group A plasma, which causes functional abnormalities of both $\mathrm{T} 4+$ suppressor inducer and $\mathrm{T} 8+$ suppressor effector subsets, was $1.56 \pm 0.18$. The killing ratio of $\mathrm{T} 8+/ \mathrm{T} 4+$ by group $B$ plasma, which affects predominantly the $\mathrm{T} 8+$ suppressor effector subset, was

Table VI. Reactivity of JRA Anti-T Cell Antibodies with Residual T4 Cells after Lysis with SLE Antibodies and C

\begin{tabular}{lccc} 
& \multicolumn{3}{c}{ Percent reactivity* } \\
\cline { 2 - 4 } SLE plasma & JRA sera & Anti-T4 & Anti-T8 \\
\hline Patient 2 & & & \\
$\quad$ Control T4 & 41 & $>95$ & $<5$ \\
T4§ & 5 & $>95$ & $<5$ \\
Patient 4 & & & \\
Control T4 & 43 & $>95$ & $<3$ \\
T4§ & 7 & $>95$ & $<3$ \\
Patient 7 & & & \\
Control T4 & 39 & $>95$ & $<5$ \\
T4§ & 37 & $>95$ & $<5$ \\
Patient 12 & & & \\
Control T4 & 36 & $>95$ & $<2$ \\
T4§ & 9 & $>95$ & $<2$ \\
\end{tabular}

* Reactivity of JRA anti-T cell antibodies and monoclonal antibodies with T4 cells was determined by indirect immunofluorescence on FACS.

₹ Control T4 cells were treated with $\mathrm{AB}$ plasma and $\mathrm{C}$. $\S \mathrm{T} 4$ cells were treated with SLE plasma and C.
$3.43 \pm 0.66$. The killing ratio of $\mathrm{T} 8+/ \mathrm{T} 4+$ by group $\mathrm{C}$, which affects the $\mathrm{T} 4+$ suppressor inducer subset, was $1.33 \pm 0.20$. The killing ratio of $\mathrm{T} 8+/ \mathrm{T} 4+$ by group $\mathrm{D}$ plasma, which had no detectable functional effect, was $1.73 \pm 0.13$. These results suggest that generally $\mathrm{T}$ cell antibodies of all groups killed T8+ cells more than T4+ cells, but that antibodies in group B preferentially killed $\mathrm{T} 8+$ cells to the greatest extent.

Relationship between $T$ cell subset ratio of patients and the ant $i-T$ cell reactivity of their plasma

Next, we examined the T cell subsets of the SLE patients whose plasma had been studied. As shown in Fig. 6, the T4+/T8+ ratio of group A patients was $0.80 \pm 0.12$, that of group B patients, $3.46 \pm 0.48$, that of group $C$ patients, $1.12 \pm 0.24$, and that of group $D$ patients, $1.33 \pm 0.18$. These results indicate that patients in group $B$ have a high $\mathrm{T} 4+/ \mathrm{T} 8+$ ratio, but in the other groups (A, C, D), a low T4+/T8+ ratio was found compared with the normal $\mathrm{T} 4+/ \mathrm{T} 8+$ ratio (shown in shaded area). Group A patients

Table VII. Reactivity of SLE Anti-T Cell Antibodies with Radioresistant T4 Cells

\begin{tabular}{lcc} 
& \multicolumn{2}{c}{$\operatorname{IgG}$ synthesis $(\mathrm{ng} / \mathrm{ml})^{*}$} \\
\cline { 2 - 3 } SLE plasma & B + T4Rx & B + T4 ${ }^{\mathrm{R}} \mathrm{Rx}$ \\
\hline Patient 2 & 12,500 & 13,100 \\
Patient 4 & 9,600 & 9,400 \\
Patient 12 & 7,900 & 8,500 \\
\hline
\end{tabular}

${ }^{*} 5 \times 10^{4} \mathrm{~B}$ cells and $1 \times 10^{5} \mathrm{~T} 4$ cells treated with SLE plasma and $\mathrm{C}$, with or without irradiation were stimulated with PWM. $\mp T 4 R x$ were treated with SLE plasma and C. $\S \mathrm{T} 4^{\mathrm{R}}$, irradiated $1,250 \mathrm{rad}$. 
Table VIII. T4 Irradiated and T4 Cells Treated with SLE Plasma and C Cannot Mediate Suppressor Inducer Function

\begin{tabular}{|c|c|c|c|}
\hline \multirow[b]{2}{*}{ Cell combinations } & \multirow[b]{2}{*}{$\begin{array}{l}\text { T8 cells } \\
\text { added }\end{array}$} & \multicolumn{2}{|c|}{$\operatorname{IgG}(\mathrm{ng} / \mathrm{ml})^{*}$} \\
\hline & & $\begin{array}{l}\text { Treatment of } \\
\text { pt. } 2 \text { plasma }\end{array}$ & $\begin{array}{l}\text { Treatment of } \\
\text { pt. } 12 \text { plasma }\end{array}$ \\
\hline \multirow[t]{2}{*}{ A. B $+\mathrm{T} 4$ cont‡ } & 0 & 16,700 & 13,900 \\
\hline & + & $2,450(85)^{\prime \prime}$ & $1,570(89)$ \\
\hline \multirow[t]{2}{*}{ B. $\mathrm{B}+\mathrm{T} 4^{\mathrm{R}} \S$} & 0 & 10,500 & 9,700 \\
\hline & + & $9,800(7)$ & $9,500(2)$ \\
\hline \multicolumn{4}{|l|}{ C. $B+$ mixture of $T 4^{R}$} \\
\hline \multirow[t]{2}{*}{ and $\mathrm{T} 4$ cont $(1: 1)$} & $\mathbf{0}$ & 12,500 & 13,000 \\
\hline & + & $3,500(72)$ & $2,100(84)$ \\
\hline \multicolumn{4}{|l|}{ D. $B+$ mixture of $T 4^{R}$} \\
\hline \multirow[t]{2}{*}{ and T4Rx $(1: 1)$} & 0 & 13,500 & 12,800 \\
\hline & + & $12,900(4)$ & $13,200(-3)$ \\
\hline
\end{tabular}

* $5 \times 10^{4}$ B cells and $2 \times 10^{4}$ T4 cells were stimulated with PWM. In some experiments, $2 \times 10^{4} \mathrm{~T} 8$ cells were added to these mixtures. $\ddagger \mathrm{T} 4$ cont, $\mathrm{T} 4$ cells treated with $\mathrm{AB}$ plasma and $\mathrm{C}$ $\S \mathrm{T} 4^{\mathrm{R}}$, irradiated $1,250 \mathrm{rad}$.

"Number in parentheses equals percent suppression and was calculated as described in Table I.

I T4Rx, T4 cells treated with SLE plasma and C.

had the lowest $\mathrm{T} 4+/ \mathrm{T} 8+$ ratio. The relationship between the $\mathrm{T} 4+/ \mathrm{T} 8+$ ratio of these groups and the T8+/T4+ killing by anti-T cell antibodies was analyzed. As shown in Fig. 7, there was a significant correlation between $\mathrm{T} 4+/ \mathrm{T} 8+$ ratio and $\mathrm{T} 8+/$ T4+ killing $(\gamma=0.666, P<0.001)$. These results suggest that

Table IX. Effect of SLE Plasma Treatment after Absorption of $B$ Cell Lines on IgG Production

\begin{tabular}{lllll}
\hline & & \multicolumn{3}{c}{ Suppression of IgG synthesis* } \\
\cline { 3 - 5 } SLE plasma & Absorption & Control & T4Rx & T8Rx \\
\hline \multirow{3}{*}{ Patient 2 } & & $\%$ & $\%$ & $\%$ \\
& - & $60 \ddagger$ & 10 & 7 \\
Patient 7 & + & 63 & 14 & 10 \\
& + & 70 & 73 & 12 \\
Patient 12 & + & 65 & 67 & 9 \\
& + & 79 & 14 & 71 \\
& + & 73 & 9 & 66 \\
\hline
\end{tabular}

* Normal T4 and T8 T cells, B cells and macrophages were stimulated with PWM and assayed for IgG synthesis. In addition, either the T4+ (T4Rx) or the T8 cells (T8Rx) were pretreated with SLE plasma absorbed with and without $B$ cell lines and $C$.

‡ Percent suppression was calculated as described in Table I.

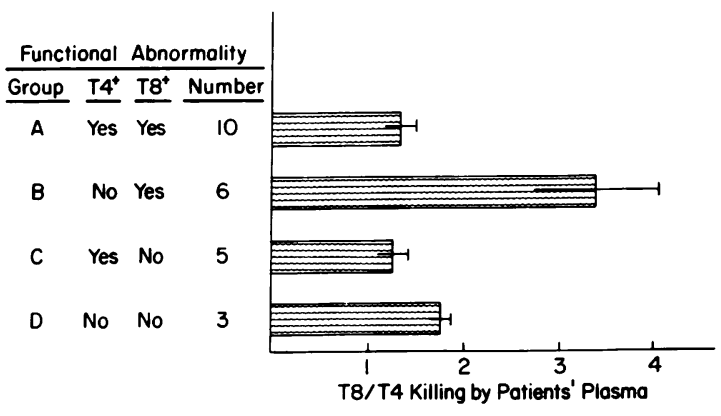

Figure 5. Relationship between effect of anti-T cell antibodies on $T$ cell functions and their ability to kill $\mathrm{T}$ cell subsets. T8+/T4+ killing represents the ratio of normal T8+ cells killed to T4+ cells killed by the SLE plasma and C. Group B plasma that killed T8+ cells to a substantially greater extent than $\mathrm{T} 4+$ cells also interfered selectively with $\mathrm{T} 8+$ function.

anti-T cell antibodies found in these patients may play a role in removing their reactive $T$ cell subsets and in helping to determine the $\mathrm{T} 4+/ \mathrm{T} 8+$ ratio in vivo.

\section{Discussion}

The present study represents an attempt to understand the specificities of SLE anti-T cell antibodies in their interference with suppression of Ig synthesis. This study was undertaken because SLE is predominantly an antibody-mediated disease and because suppressor cell dysfunction and anti-T cell antibodies have been reported previously (15-26). We confirm previous findings that SLE anti-T cell antibodies occur in SLE and extend them to a definition of specificities. Although we concentrated upon suppressor function, we fully recognize that there are additional unrelated specificities. Nevertheless, we found that some patients have anti-T cell antibodies that react preferentially with T8+ suppressor effector cells whereas others react preferentially with T4+ suppressor inducer cells. Additional patients had both specificities and a few had neither. Furthermore, the activity of

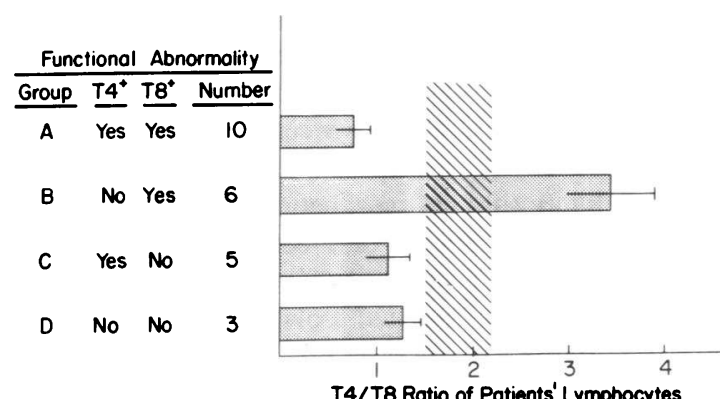

Figure 6. Relationship between $\mathrm{T}$ cell function reduction by patients' plasma and their $\mathrm{T} 4+/ \mathrm{T} 8+$ ratios. Group B patients had the highest $\mathrm{T} 4+/ \mathrm{T} 8+$ ratios and their plasma selectively eliminated $\mathrm{T} 8+$ suppressor function. 


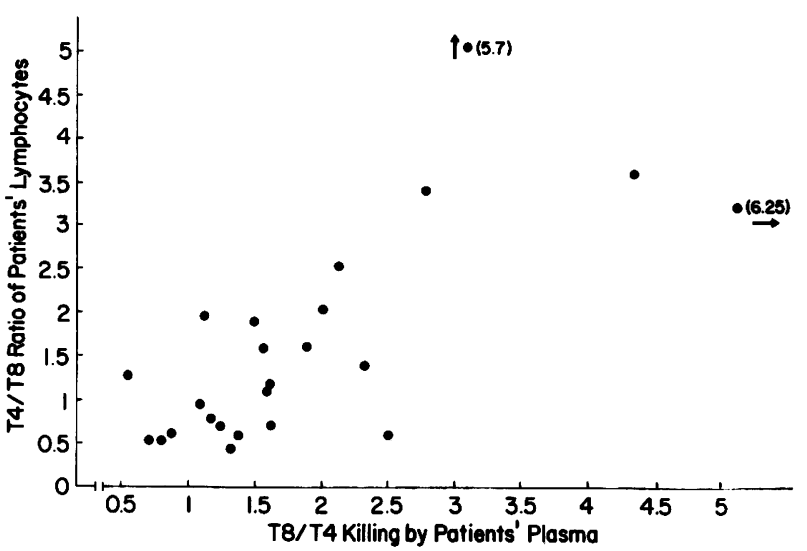

Figure 7. Relationship between T cell subset ratio of SLE patients' cells and the reactivity of the anti-T cell antibodies of their plasma. The T4+/T8+ ratio of the patients' cells was strongly correlated $(\gamma$ $=0.666, P<0.001$ ) with the ability of their plasma to kill T8+ cells relative to $\mathrm{T} 4+$ cells (the $\mathrm{T} 8+/ \mathrm{T} 4+$ killing ratio).

anti-T cell antibodies in SLE patients in our systems seemed to be due to IgM anti-T cell antibodies. It is conceivable that the present study measured the effect of $\mathrm{C}$-mediated killing of $T$ cells. It has previously been shown in mice that IgM antibodies to $\mathrm{T}$ cells are $\mathbf{5 0 0}$ times more efficient at $\mathrm{C}$-mediated lysis than are IgG antibodies (36). In human SLE, Sakane et al. (24) also have reported that IgM anti-T cell antibodies were shown to possess the inhibitory property and $\mathrm{C}$ was found to be necessary for the maximal effect of such anti-T cell antibodies. There was a significant correlation between the ability of SLE anti-T cell antibodies to kill $\mathrm{T} 4+$ and $\mathrm{T} 8+$ subsets and the relative proportions of T4+ and T8+ cells in the blood of the donors of the antibodies. Thus, the $\mathrm{T} 8+/ \mathrm{T} 4+$ killing ratio by the antibodies was correlated with the $\mathrm{T} 4+/ \mathrm{T} 8+$ ratio of the lymphocytes of the same patients. This inverse relationship between the circulating T4+/T8+ lymphocyte ratio and the T4+/T8+ killing ratio suggested that the antibodies may have affected the circulating $T$ cells by preferential elimination of one or another subset. In support of this was the observation that patients with antibodies that eliminated T8+-mediated suppressor effector function had the highest T4+/T8+ lymphocyte ratios. Thus, despite the relatively crude division of $\mathrm{T}$ cells into two major subsets, a relationship was obtained between the in vitro effects of the antibodies and the in vivo $T$ cell phenotypes found in SLE patients. It is likely that an even better correlation might be obtained by further subdivision of $\mathrm{T}$ cell subsets.

To characterize the anti-T cell antibodies from SLE patients, we used $\mathrm{C}$-mediated lysis of normal isolated $\mathrm{T}$ lymphocytes. To exclude the possibility that the functional abnormalities seen after treating T4+ and T8+ cells with SLE plasma and C were due to blocking of effector molecules by residual antibodies including both anti-T cell and anti-Ia antibodies, we incubated T4+ or T8+ cells with SLE plasma without C, and did similar experiments since SLE sera contain anti-Ia antibodies (49). In these experiments, no loss of T4+ suppressor inducer function or T8+ suppressor effector function was observed (data not shown). Furthermore, even though SLE plasma was absorbed with B cell lines extensively, similar functional results were obtained after treatment of T4+ or T8+ cells with absorbed or nonabsorbed SLE plasma and C. The SLE plasma also did not block the binding of monoclonal anti-T4 or anti-T8 binding to cells (data not shown). This result suggests that anti-T cell antibodies present in SLE patients and reactive with T4+ and/or T8+ cells were either of lower affinity than anti-T8 and anti$\mathrm{T} 4$ or were directed against distinct determinants or different epitopes.

Our earlier studies demonstrated that plasma from active SLE patients with multisystem involvement contained antibodies selectively reactive with T8+ suppressor cells (25). Analysis of $T$ cell subsets in such patients showed a decrease of $T 8+$ suppressor cells resulting in a high T4+/T8+ ratio (39). More recently, studies in additional patients demonstrated that patients with severe renal disease and/or thrombocytopenia without other systemic manifestations had a decreased number of T4+ inducer cells and increased number of T8+ suppressor cells resulting in low $\mathrm{T} 4+/ \mathrm{T} 8+$ ratio $(40,41)$. Anti-T cell antibodies found in these patients were reactive with $\mathrm{T} 4+$ suppressor inducer cells or were reactive with both $\mathrm{T} 4+$ suppressor inducer and $\mathrm{T} 8+$ suppressor effector cells. The former specificity of anti-T cell antibodies is similar to that seen in some patients with JRA and previously described as JRA anti-T cell antibodies $(34,47$, 48). Such antibodies may occur even more commonly in patients with SLE than in patients with JRA.

There are several strains of mice that develop disease resembling human SLE $(50,51) . \mathrm{MRL}-1 \mathrm{pr} / 1 \mathrm{pr},(\mathrm{NZB} \times \mathrm{NZW})$ $F_{1}, B X S B$, and NZB mice illustrate both the complexity and the variety of immunoregulatory abnormalities (50-54). Thus, the details of the immunoregulatory defects may be different in various mouse strains $(50,53)$. It appears that a similar spectrum may characterize a large group of humans with SLE.

Taken together, the present results support the notion that in SLE, different cellular defects of immunoregulatory circuits may underlie their development of autoimmunity $(40,41)$. With regard to defects in suppressor cell function for IgG synthesis, we suggest that one type of SLE may be characterized by defects of $\mathrm{T} 8+$ suppressor cells, another type by an abnormality of the T4+ suppressor inducer subset, and a third by impaired functions of both the T4+ suppressor inducer subset and the T8+ suppressor effector cells. Furthermore, our results suggest that $T$ cell antibodies found in these patients play a role in the defects in these immunoregulatory circuits. However, additional cellular defects are likely to be present in patients with SLE. Further study of the immune system will allow more precise understanding of specific cellular defects in individual patients; these insights may provide more individualized approaches to patient management.

\section{Acknowledgments}

We would like to express our gratitude to Dr. P. Romain for many helpful discussions. We would also like to thank Mr. John Cheney for his skillful assistance. 
This work was supported by National Institutes of Health grants AI 12069, CA 12069, CA 19589, and R01 NS 17182.

\section{References}

1. Koffler, D., P. H. Schur, and H. G. Kunkel. 1967. Immunological studies concerning the nephritis of systemic lupus erythematosus. $J$. Exp. Med. 126:607-623.

2. Stastney, P., and M. Ziff. 1971. Antibodies against cell membrane constituents in systemic lupus erythematosus and related diseases. I. Cytotoxic effect of serum from patients with systemic lupus erythematosus (SLE) for allogeneic and for autologous lymphocytes. Clin. Exp. Immunol. 8:543-550.

3. Lies, R. B., R. P. Messner, and R. C. Williams, Jr. 1973. Relative $T$ cell specificity of lymphocytotoxins from patients with systemic lupus erythematosus. Arthritis Rheum. 16:369-375.

4. Wernet, P., and H. G. Kunkel. 1973. Antibodies to a specific surface antigen of $\mathrm{T}$ cells in human sera inhibiting mixed leukocyte culture reactions. J. Exp. Med. 138:1021-1026.

5. Winfield, J. B., R. J. Winchester, P. Wernet, S. M. Fu, and H. G. Kunkel. 1975. Nature of cold reactive antibodies to lymphocyte surface determinants in systemic lupus erythematosus. Arthritis Rheum. $18: 1-5$.

6. Glinski, W., M. E. Gershwin, and A. D. Steinberg. 1976. Fractionation of cells on a discontinuous Ficoll gradient. Study of subpopulations of human $T$ cells using anti-T cell antibodies from patients with systemic lupus erythematosus. J. Clin. Invest. 57:604-614.

7. Messner, P. P., F. D. Lindstrom, and R. C. Williams, Jr. 1973. Peripheral blood lymphocyte cell surface markers during the course of systemic lupus erythematosus. J. Clin. Invest. 52:3046-3056.

8. Scheinberg, M. A., and E. S. Cathcart. 1974. B cell and T cell lymphopenia in systemic lupus erythematosus. Cell. Immunol. 12:309314.

9. Glinski, W., M. E. Gershwin, D. R. Budman, and A. D. Steinberg. 1976. Study of lymphocyte subpopulations in normal humans and patients with systemic lupus erythematosus by fractionation of peripheral blood lymphocytes on a discontinuous Ficoll gradient. Clin. Exp. Immunol. 26:228-238.

10. Horwitz, D. A. 1972. Impaired delayed hypersensitivity in systemic lupus erythematosus. Arthritis Rheum. 15:353-359.

11. Hahn, B. H., M. K. Bagby, and C. K. Osterland. 1973. Abnormalities of delayed hypersensitivity in systemic lupus erythematosus. Am. J. Med. 55:25-31.

12. Suciu-Foca, N., J. A. Buda, T. Thiem, and K. Reemtsma. 1974. Impaired responsiveness of lymphocytes in patients with systemic lupus erythematosus. Clin. Exp. Immunol. 18:295-301.

13. Rosenthal, C. J., and E. C. Franklin. 1975. Depression of cellularmediated immunity in systemic lupus erythematosus. Relation to disease activity. Arthritis Rheum. 18:207-217.

14. Sakane, T., A. D. Steinberg, and I. Green. 1978. Failure of autologous mixed lymphocyte reactions between $\mathrm{T}$ and non-T cells in patients with systemic lupus erythematosus. Proc. Natl. Acad. Sci. USA. 75:3464-3468.

15. Abdou, N. I., A. Sagawa, E. Pascal, J. Hevert, and S. Sadeghee. 1976. Suppressor T cell abnormality in idiopathic systemic lupus erythematosus. Clin. Immunol. Immunopathol. 6:192-199.

16. Bresnihan, B., and H. E. Jasin. 1977. Suppressor function of peripheral blood mononuclear cells in normal individuals and patients with systemic lupus erythematosus. J. Clin. Invest. 59:106-116.

17. Morimoto, C. 1978. Loss of suppressor T lymphocyte function in patients with SLE. Clin. Exp. Immunol. 32:125-133.
18. Sakane, T., A. D. Steinberg, and I. Green. 1978. Studies of immune function of patients with SLE. I. Dysfunction of suppressor T cell activity related to impaired generation of, rather than response to, suppressor cells. Arthritis Rheum. 21:657-664.

19. Sagawa, A., and N. I. Abdou. 1978. Suppressor cell dysfunction in systemic lupus erythematosus. Cell involved and in in vitro correction. J. Clin. Invest. 62:789-796.

20. Fauci, A. S., A. D. Steinberg, B. F. Haynes, and G. Whalen. 1978. Immunoregulatory aberrations in systemic lupus erythematosus. J. Immunol. 121:1473-1479.

21. Kumagai, S., A. D. Steinberg, and I. Green. 1981. Immune responses to hapten-modified self and their regulation in normal individuals and patients with SLE. J. Immunol. 127:1643-1652.

22. Sagawa, A., and N. I. Abdou. 1979. Suppressor cell antibody in systemic lupus erythematosus: possible mechanism for suppressor cell dysfunction. J. Clin. Invest. 63:536-539.

23. Morimoto, C., T. Abe, T. Toguchi, M. Kiyotaki, and M. Homma. 1979. Studies of anti-lymphocyte antibody of patients with active SLE. I. Cause of loss of suppressor T lymphocyte function. Scand. J. Immunol. 10:213-221.

24. Sakane, T., A. D. Steinberg, J. P. Reeves, and I. Green. 1979. Studies of immune functions of patients with systemic lupus erythematosus. Complement-dependent immunoglobulin $\mathbf{M}$ anti-thymus-derived cell antibodies preferentially inactivate suppressor cells. J. Clin. Invest. 63:954-965.

25. Morimoto, C., E. L. Reinherz, T. Abe, M. Homma, and S. F. Schlossman. 1980. Characteristics of anti-T cell antibodies in SLE: evidence for selective reactivity with normal suppressor cells defined by monoclonal antibodies. Clin. Immunol. Immunopathol. 16:474-484.

26. Hirata, F., R. del Carmine, C. A. Nelson, J. Axelrod, E. Shiffman, A. Warabi, A. L. DeBlas, M. Nirenberg, V. Manganiello, M. Vaughan, S. Kumagai, I. Green, J. L. Decker, and A. D. Steinberg. 1981. Presence of autoantibody for phospholipase inhibitory protein, lipomodulin, in patients with rheumatic diseases. Proc. Natl. Acad. Sci. USA. 78:31903194.

27. Delfraissy, J. F., P. Segond, P. Galanaud, C. Wallon, P. Massias, and J. Dormont. 1980. Depressed primary in vitro antibody response in untreated systemic lupus erythematosus. T helper cell defect and lack of defective suppressor cell function. J. Clin. Invest. 66:141-148.

28. Reinherz, E. L., P. C. Kung, G. Goldstein, and S. F. Schlossman. 1979. Separation of functional subsets of human T cells by a monoclonal antibody. Proc. Natl. Acad. Sci. USA. 76:4061-4065.

29. Reinherz, E. L., P. C. Kung, G. Goldstein, and S. F. Schlossman. 1979. Further characterization of the human inducer $T$ cell subset defined by monoclonal antibody. J. Immunol. 123:2894-2896.

30. Reinherz, E. L., P. C. Kung, J. M. Breard, G. Goldstein, and S. F. Schlossman. 1980. T cell requirements for generation of helper factors in man. Analysis of the subsets involved. J. Immunol. 124:18831887.

31. Smolen, J. S., T. A. Luger, T. M. Chused, and A. D. Steinberg. 1981. Responder cells in the human autologous mixed lymphocyte reaction. J. Clin. Invest. 68:1601-1604.

32. Smolen, J. S., T. M. Chused, E. A. Novotny, and A. D. Steinberg. 1982. The human autologous mixed lymphocyte reaction. III. Immune circuits. J. Immunol. 129:1050-1053.

33. Damle, N. K., J. A. Hansen, R. A. Good, and S. Gupta. 1981. Monoclonal antibody analysis of human $\mathrm{T}$ lymphocyte subpopulations exhibiting autologous mixed lymphocyte reaction. Proc. Natl. Acad. Sci. USA. 78:5096-5098.

34. Morimoto, C., E. L. Reinherz, Y. Borel, E. Mantzouranis, A. D. Steinberg, and S. F. Schlossman. 1981. Autoantibody to an im- 
munoregulatory inducer population in patients with juvenile rheumatoid arthritis. J. Clin. Invest. 67:753-761.

35. Thomas, Y., J. Sosman, O. Irigoyen, S. J. Friedman, P. C. Kung, G. Goldstein, and L. Chess. 1980. Functional analysis of human T cell subsets defined by monoclonal antibodies. I. Collaborative T-T interactions in the immunoregulation of B cell differentiation. J. Immunol. 125:2402-2408.

36. Klassen, L. W., R. S. Krakauer, and A. D. Steinberg. 1977. Selective loss of suppressor cell function in New Zealand mice induced by NTA. J. Immunol. 119:830-837.

37. Litvin, D. A., P. L. Cohen, and J. B. Winfield. 1983. Characterization of warm reactive IgG anti-lymphocyte antibodies in systemic lupus erythematosus: relative specificity for mitogen-activated $\mathrm{T}$ cells and their soluble products. J. Immunol. 130:181-186.

38. Kumagai, S., A. D. Steinberg, and I. Green. 1981. Antibodies to $T$ cells in patients with systemic lupus erythematosus mediated antibody-dependent cell-mediated cytotoxicity against human $T$ cells. $J$. Clin. Invest. 67:605-614.

39. Morimoto, C., E. L. Reinherz, S. F. Schlossman, P. H. Schur, J. A. Mills, and A. D. Steinberg. 1980. Alterations in immunoregulatory $\mathrm{T}$ cell subsets in active systemic lupus erythematosus. J. Clin. Invest. 66:1171-1174.

40. Smolen, J. S., T. M. Chused, W. M. Leiserson, J. P. Reeves, D. Alling, and A. D. Steinberg. 1982. Heterogeneity of immunoregulatory $\mathrm{T}$ cell subsets in systemic lupus erythematosus. Correlation with clinical features. Am. J. Med. 72:783-790.

41. Smolen, J. S., C. Morimoto, T. M. Chused, E. L. Reinherz, W. Leiserson, J. P. Reeves, S. F. Schlossman, and A. D. Steinberg. 1982. $\mathrm{T}$ cell subsets in systemic lupus erythematosus (SLE): correlation with clinical features. Arthritis Rheum. 25(Suppl.):36. (Abstr.)

42. Morimoto, C., R. F. Todd, J. A. Distaso, and S. F. Schlossman. 1981. The role of the macrophage in in vitro primary anti-DNP antibody production in man. J. Immunol. 127:1137-1141.

43. Reinherz, E. L., P. C. Kung, G. Goldstein, and S. F. Schlossman. 1979. A monoclonal antibody with selective reactivity with functionally mature human thymocytes and all peripheral human T cells. J. Immunol. 123:1312-1317.
44. Todd, R. F., L. M. Nadler, and S. F. Schlossman. 1981. Antigens on human monocytes identified by monoclonal antibodies. J. Immunol. 126:1435-1442.

45. Stashenko, P., L. M. Nadler, R. Hardy, and S. F. Schlossman. 1980. Characterization of a human B lymphocyte specific antigen. $J$. Immunol. 125:1678-1682.

46. Reinherz, E. L., P. C. Kung, G. Goldstein, and S. F. Schlossman. 1980. A monoclonal antibody reactive with the human cytotoxic/suppressor cell subset previously defined by a heteroantiserum termed $\mathrm{TH}_{\mathbf{2}}$. J. Immunol. 124:1301-1307.

47. Morimoto, C., J. Distaso, Y. Borel, S. F. Schlossman, and E. L. Reinherz. 1982. Communicative interactions between subpopulations of human $\mathrm{T}$ lymphocytes required for generation of suppressor effector function in a primary antibody response. J. Immunol. 128:16451650.

48. Morimoto, C., E. L. Reinherz, Y. Borel, and S. F. Schlossman. 1983. Direct demonstration of the human suppressor inducer subset by anti-T cell antibodies. J. Immunol. 130:157-161.

49. Okudaira, K., R. P. Searles, J. L. Ceuppens, J. S. Goodwin, and R. C. Williams, Jr. 1982. Anti-Ia reactivity in sera from patients with systemic lupus erythematosus. J. Clin. Invest. 69:17-24.

50. Steinberg, A. D., D. P. Huston, J. D. Taurog, J. S. Cowdery, and E. S. Raveche. 1981. The cellular and genetic basis of murine lupus. Immunol. Rev. 55:121-154.

51. Theofilopoulos, A. N., and F. J. Dixon. 1981. Etiopathogenesis of murine SLE. Immunol. Rev. 55:179-216.

52. Eastcott, J. W., R. S. Schwartz, and S. K. Datta. 1981. Genetic segregation of $B$ cell hyperactivity and autoimmunity in crosses of NZB mice. Fed. Proc. 40:1058.

53. Steinberg, A. D., E. S. Raveche, C. A. Laskin, M. L. Miller, and R. T. Steinberg. 1982. Genetic, environmental, and cellular factors in the pathogenesis of systemic lupus erythematosus. Arthritis Rheum. 25:734-743.

54. Cantor, H., L. McVay-Boudreau, J. Hugenberger, N. Naidorf, F. W. Shen, and R. K. Gershon. 1978. Immunoregulatory circuits among T cell sets. II. Physiological role of feedback inhibition in vivo: absence in NZB mice. J. Exp. Med. 147:1116-1125. 